\title{
ROMANIA AS AN EU MEMBER STATE: OPPORTUNITIES, RESPONSIBILITIES, CHALLENGES IN ENTREPRENEURIAL ACTIVITY

\author{
https://doi.org/10.47743/jopafl-2021-19-11
}

\author{
Lorena Florentina DUMITRAȘCIUC \\ Alexandru Ioan Cuza University of Iasi, Romania \\ Doctoral School of Economics and Business Administration \\ lorena.popescul@gmail.com \\ Loredana JITARU \\ Alexandru Ioan Cuza University of Iasi, Romania \\ jitaru_loredana10@yahoo.com
}

\begin{abstract}
Entrepreneurship is usually associated with younger people, such as those aged 18-40. A great opportunity that could benefit Romania as EU support is to focus on middle-aged entrepreneurs over 40 years. In order to accomplish this research, we have conducted a comparative between the characteristics of young people and the middle-aged determining entrepreneurial behaviour in Romania and who want to open a start-up. For this purpose, we have considered applying questionnaires for the two target groups. One of Romania's responsibilities towards young entrepreneurs and the second-age entrepreneurs at the start-up level is related to the increase in the number of entrepreneurial programs at national level by attracting EU funds, reducing the bureaucratic system, but also by providing facilities tax policy that makes the entrepreneur no longer burdened.
\end{abstract}

Keywords: Romania, EU, entrepreneur, opportunities, challenges

JEL Classification: L22, L26, O10, O15, O30.

\section{Introduction}

In the EU context, Romania should focus on enhancing the entrepreneurial role as it is the engine of economic development and recovery (Fuentelsaz et al., 2015). In addition, entrepreneurship is all the more useful that the baby boom generation will retire, the government will not have enough money to pay for pensions, the price of oil will explode, the dollar will devalue, and inflation will fall out of control (Trump and Kiyosaki, 2008). Usually, entrepreneurship is associated with younger people (Kelley, 2009; Wennekers et al., 2010), such as those aged 18-40 because young people take risks in contrast to the elderly. However, a great opportunity for Romania to benefit from EU support is to focus on second-age entrepreneurs (Kautonen et al., 2011) for more than 40 years.nGiven that the entrepreneurial activity of the elderly is an underestimated area, this area requires a thorough study (Kautonen, 2008).

\section{Entrepreneurship in Romania, a theoretical perspective}

Today there are many social, political and economic challenges facing organizations. Thus, entrepreneurs need to innovate in the field to achieve valuable results 
(Dumitrașciuc and Jitaru, 2019). Also, entrepreneurs are the ones who contribute to changing the way we live and the way we work (Dumitrașciuc, 2019). Regarding entrepreneurship through opportunity, it does not develop only in developed countries Mota et al. (2019), but also in developing countries.

Entrepreneurship through opportunity does not only develop in developed countries Mota et al. (2019), but also in developing countries. Romania needs EU support in this case, especially as small firms are increasingly struggling to maintain the same level of entrepreneurial effort as they grow. In this way, small firms turn to activities that aim at reducing the level of risk and also aim at strengthening the company's position (Collinson, 2001). But a significant role in entrepreneurial firms has its innovation, because it has the capacity to change people's behaviour as well as their working methods (Galindo and Méndez, 2014). Thus, entrepreneurial organizations can innovate either a new product or service, or they can come up with a number of improvements to a particular product or service based on the results of some new technologies or even on combinations of new technologies.

The innovation that an entrepreneur can bring can be linked to a particular product or service, may be linked to the process, marketing and sales, company management, financial, and organizational part in general. Thus, the European Union is a major actor and a leader in the scientific and technological activity of entrepreneurial organizations (European Commission, 2014).

The European Commission (2014, p.3) argues that "Europe's future is linked to its capacity for innovation, transforming great ideas into products and services that create both economic growth and jobs. For example, the Innovation Union initiative as an EU strategy to promote this process aims to provide an environment in which Europe will encourage new ideas. In practice, the Innovation Union initiative is part of the EU's growth strategy and is entitled "Europe 2020", which foresees that the public and private sectors reach a cumulative level of investment in research and innovation of $3 \%$ of gross domestic product (GDP) by 2020."

As far as Romanians are concerned, entrepreneur Ghenea (2011, p.313-315) tells us that Romanian entrepreneurs have a number of strong points. They are intelligent because the Romanian entrepreneurs come with out-of-the-box solutions to various problems that arise in everyday life, which means they can be turned into opportunities.

Last but not least, Romanian entrepreneurs have good communication skills. In addition to strengths, there are also some weak points, such as lack of decision-making capacity in a quick way, as they focus very much on the "best decision". Just what they do not know is that there is never the "best decision". Each decision brings a number of results and consequences.

Another weak point is that entrepreneurs out of too much creativity do not support their idea of a feasible plan, which most of the time, the idea no longer develops and remains only at the stage of project or idea, without ever being implemented. And here we can talk about a lack of vision of entrepreneurs on the business as a whole. Also in the weaknesses category, we found the lack of delegation or insufficient delegation of key responsibilities from the entrepreneur to the people in his company (Akcigit, et. al, 2018). This is because the entrepreneur does not have enough confidence in his employees either because he likes to have excessive control over everything that's going on in the organization. So entrepreneurs need to have an overall vision if they want to be successful (Maxwell, 2012). 
Another aspect for which Romanian entrepreneurs do not delegate enough of their responsibilities is that they like to be prudent in what they do (Kalirajan and Shand, 1994). So all these decisions only make employees feel aside for the simple reason that the entrepreneur makes the decision to do everything by himself, and because he goes on the principle of "I know best what I have to do."

Finally, another weak point of Romanian entrepreneurs is their lack of preparation as regards the financial planning of the business. This is because entrepreneurs rely on their own intuition and not on analyzing and planning the organization's cash flow. That is why a significant role is played by entrepreneurship and financial education courses that could be facilitated through the European Union, especially for those who have a start-up. These EU courses would also be indicated for families that do not have a revenue and expenditure budget planning. Romania needs EU support in this case, especially as small firms are increasingly struggling to maintain the same level of entrepreneurial effort as they grow. Therefore, Romania as an EU member state must focus on the innovation side, in which to implement their passions and talents, their creativity and the qualities they have in order to have a society that develops economically.

\section{Methodology}

In the report by the European Commission (2014, p.11) it was found that "according to the World Health Organization, physical and social environments are among the main factors that can help us remain healthy, independent and autonomous as we age. Therefore, creating appropriate environments for second-age entrepreneurs is one of the most effective ways to respond to demographic changes."

Therefore, we propose to answer three questions of the research:

(1) What are the characteristics of young people who determine entrepreneurial behaviour in Romania?

(2) What are the characteristics of the elderly people who determine the entrepreneurial behaviour in Romania? and

(3) What are the opportunities, responsibilities and challenges that Romania can benefit from as an EU Member State and growth and economic development?

Starting from the general objective and the research questions we have formulated the following specific objectives:

O1: Analysis of entrepreneurial skills on entrepreneurial behaviour.

O2: Analyze opportunities to become an entrepreneur on their behaviour.

O3: Analysis of the satisfaction with the quality of personal and professional life on the behaviour of entrepreneurs.

Starting from the specific objectives, we proposed the following working hypotheses, as follows:

O1: Analysis of entrepreneurial skills on entrepreneurial behaviour.

H1: Passion positively influences the decision to open a start-up.

O2: Analysis of Opportunities to Become an Entrepreneur of Behaviour of Entrepreneurs.

H2: Innovation positively influences the decision to open a start-up.

O3: Analysis of the satisfaction with the quality of personal and professional life on the behaviour of entrepreneurs. 
H3: The balance between personal life and professional life has a positive influence on the decision to open a start-up.

In order to accomplish this research, we conducted a comparative analysis of the characteristics of young people and those of the second age who determine the entrepreneurial behaviour in Romania and who want to open a start-up. For this we applied online survey based on online questionnaire, opinion poll technique, and data collection process from respondents. For this purpose, we applied online questionnaires to the two target groups: young entrepreneurs and second-age entrepreneurs. The total number of respondents was 60 future Romanian entrepreneurs. They were picked up from Facebook Ads. Of the 60 respondents, we had 30 young entrepreneurs and 30 second-age entrepreneurs who want to open up an IT start-up. We have proposed a dependent variable: the behaviour of entrepreneurs measured by the decision to open a start-up.

Regarding the independent variables, we considered: the entrepreneurial skills (passion measured over the years in the field of activity), the opportunities to become an entrepreneur (innovations measured by the number of new products or services placed on the market) and satisfaction with the quality personal and professional life (balance of personal life and professional life measured by the number of hours spent on professional and professional life).

Table 1. Dependent and independent variables

\begin{tabular}{|l|l|}
\hline Dependent variable & Independent variables \\
\hline Behaviour of entrepreneurs & The skills of the entrepreneur \\
\hline & Opportunities to become an entrepreneur \\
\hline & $\begin{array}{l}\text { Satisfaction with the quality of personal and } \\
\text { professional life }\end{array}$ \\
\hline
\end{tabular}

Source: The authors.

Before we applied the questionnaire, we conducted four introduction questions for future entrepreneurs to get along with the questions. The introduction questions were applied to the two target groups and referred to: (1) Do you propose to become an entrepreneur ?, measured by yes, no, or do not know; (2) Are you going to start an IT startup ?, measured by yes, no or not; (3) How long do you think you will open this IT start-up, measured by: 1-5 months, 5-10 months, 10-15 months, 15-20 months and over 20 months and age, specifying that the questionnaire was finished. The questionnaire itself contained 13 closed questions, with one choice, along with the socio-demographic data (see Annexes 1 and 2). So the questions have been analyzed and reviewed before administering amongst the entrepreneurs, by field specialists in order to see if the questionnaire is error-free and can be applied. Specialists were not included in the final investigation. We also looked at privacy and data protection of respondents, in which case entrepreneurs agreed to use these data for research purposes.

\section{Main Results future young entrepreneurs versus future second-age entrepreneurs}

Regarding the questionnaire applied to young entrepreneurs, we obtained the following results in terms of introduction questions:

For question no.1 Do you propose to become an entrepreneur? we obtained the following results: 
Table 2. Become future young entrepreneurs

\begin{tabular}{|l|l|l|l|l|l|}
\hline \multicolumn{2}{|l|}{ Propose_become_entrepreneur } \\
\hline \multicolumn{2}{|l|}{} & Frequency & Percent & Valid Percent & Cumulative Percent \\
\hline Valid & YES & 30 & 100.0 & 100.0 & 100.0 \\
\hline
\end{tabular}

Source: The authors.

Table 3. Become an second-age future entrepreneur

\begin{tabular}{|l|l|l|l|l|l|}
\hline \multicolumn{2}{|l|}{ Propose_become_entrepreneur } \\
\hline \multicolumn{2}{|l|}{} & Frequency & Percent & Valid Percent & Cumulative Percent \\
\hline Valid & YES & 30 & 100.0 & 100.0 & 100.0 \\
\hline
\end{tabular}

Source: The authors.

All 60 self-considered future entrepreneurs have the intention to become an entrepreneur. Regardless of age, it is never too late to start a start-up. Especially since today, the world has become more and more competitive, so entrepreneurs have to raise their level of readiness to remain or to enter (Trump and Kiyosaki, 2008).

Question no.2 Are you going to start an IT start-up?

Table 4. Start an IT start-up future young entrepreneur

\begin{tabular}{|c|c|c|c|c|c|}
\hline \multicolumn{6}{|c|}{ Open_startup } \\
\hline & & Frequency & Percent & Valid Percent & Cumulative Percent \\
\hline va & $\begin{array}{l}\text { Valid } \\
\text { YES }\end{array}$ & 30 & 100.0 & 100.0 & 100.0 \\
\hline
\end{tabular}

Source: The authors.

Table 5. Start an IT start-up self-considered future second-age entrepreneurs

\begin{tabular}{|c|c|c|c|c|c|}
\hline \multicolumn{6}{|c|}{ Open_startup } \\
\hline & & Frequency & Percent & $\begin{array}{l}\text { Valid } \\
\text { Percent }\end{array}$ & Cumulative Percent \\
\hline valid & YES & 30 & 100.0 & 100.0 & 100.0 \\
\hline
\end{tabular}

Source: The authors.

Also, all 60 future entrepreneurs have the intention to open a start-up. There must be measures to support research and innovation in entrepreneurial organizations because they are meant to actually invest in the future of Europe. These investments, in turn, help entrepreneurial organizations to compete globally. At the same time, they improve the daily lives of millions of people in Europe and around the world (European Union, 2019).

For question no. 3 How long do you think you will open this IT start-up 
Figure 1. Time open start-up self-considered future young entrepreneurs

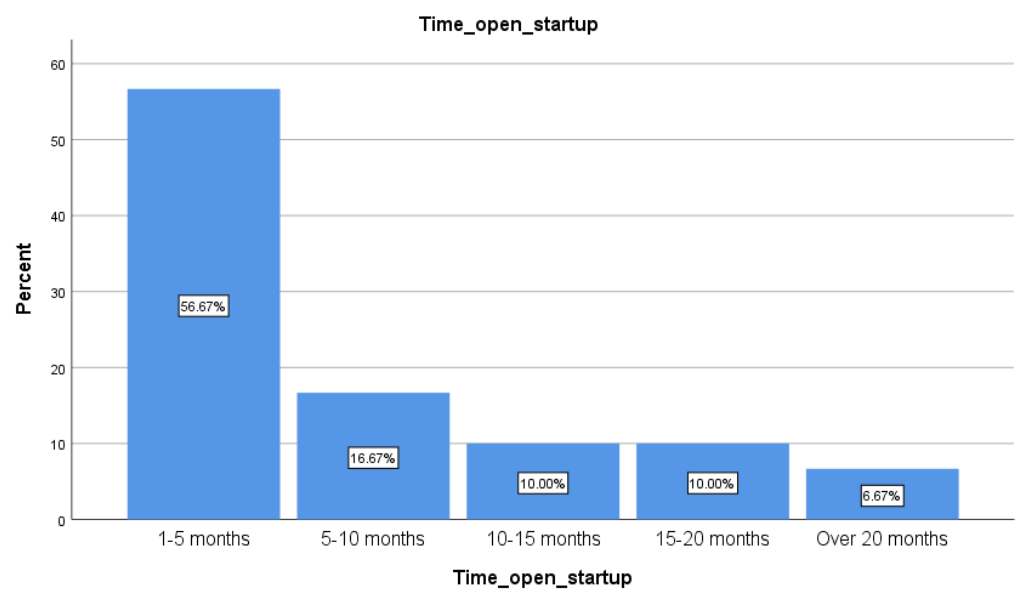

Source: The authors.

Figure 2. Time open start-up self-considered future second-age entrepreneurs

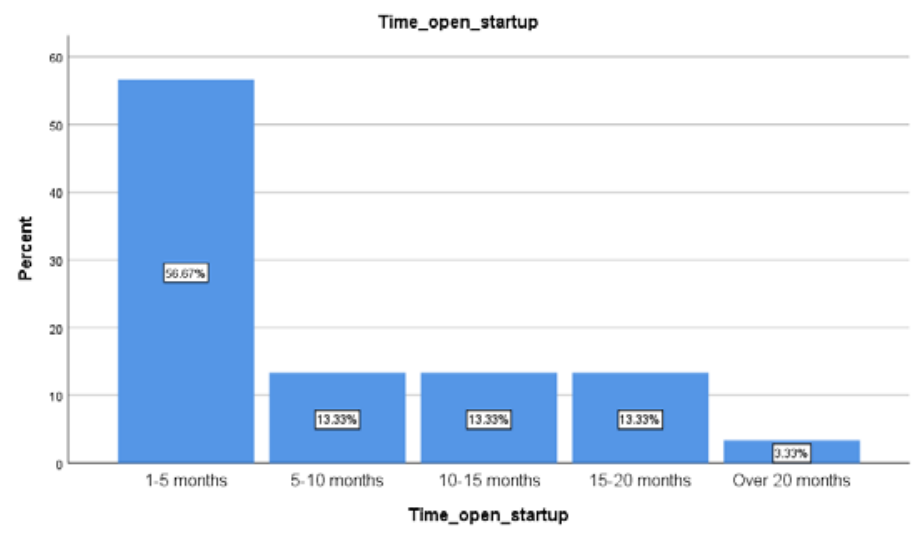

Source: The authors.

We found that data are the same in the first case for both groups of entrepreneurs, meaning that regardless of age, entrepreneurs want to open a business. $56.7 \%$ of future young entrepreneurs and self-considered future second-age entrepreneurs said they would open this IT start-up in the next 1-5 months. In Romania, entrepreneurs need to be encouraged because they represent the most valuable resource for the economic environment because entrepreneurs are the ones who contribute to job creation, they support: innovation, GDP growth, economic development and general progress of society and foster competitiveness (Popescul, 2017).

Questionnaire

For question no. (1) What are the characteristics of young people who determine the entrepreneurial behaviour in Romania?, the questionnaire included:

A. Abilities of entrepreneur: passion (measured by years of activity in the field of activity). To question no. 1 How many years do you have in the IT field?, we have obtained the following results: 
Figure 3. Years IT future young entrepreneur

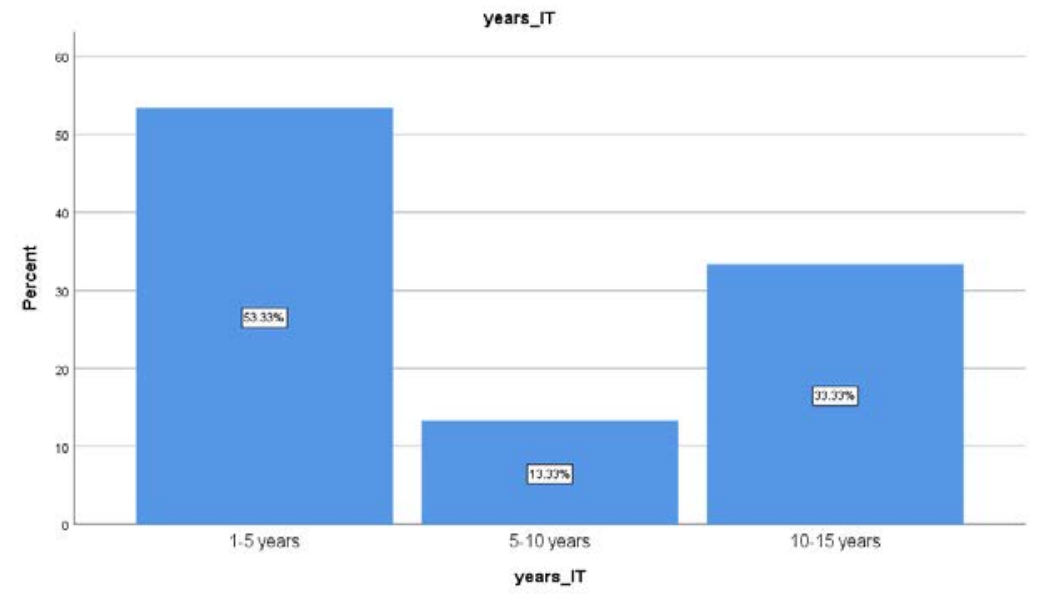

Source: The authors.

Figure 4. Years IT self-considered future second-age entrepreneurs

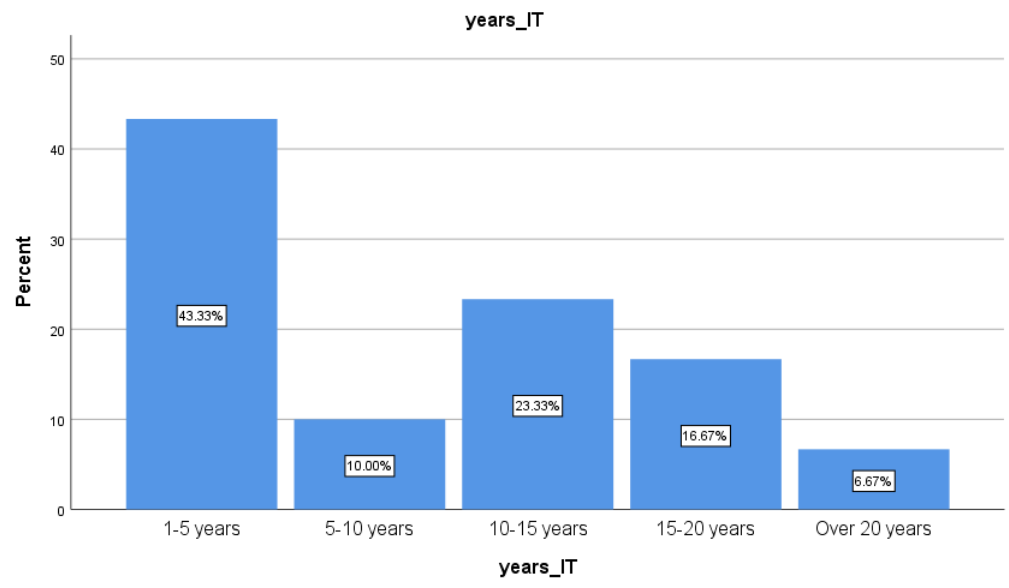

Source: The authors.

We found that 54\% self-considered future young entrepreneurs are in their first 5 years of activity, which shows their interest, enthusiasm and passion to make changes in their lives. Immediately follow those with an experience of $10-15$ years. While, $44 \%$ selfconsidered future second-age entrepreneurs are in their first 5 years of activity. Immediately follow those with an experience of 10-15 years like self-considered future young entrepreneurs. These results indicate to us that romanian entrepreneurs are creative because they come with innovative ideas unlike Central Europe that go on ideas already tested (Ghenea, 2011, p.313-315).

Question no. 2 What made you choose IT entrepreneurship? has provided us with the following information: 
Figure 5. Choose IT self-considered future young entrepreneurs

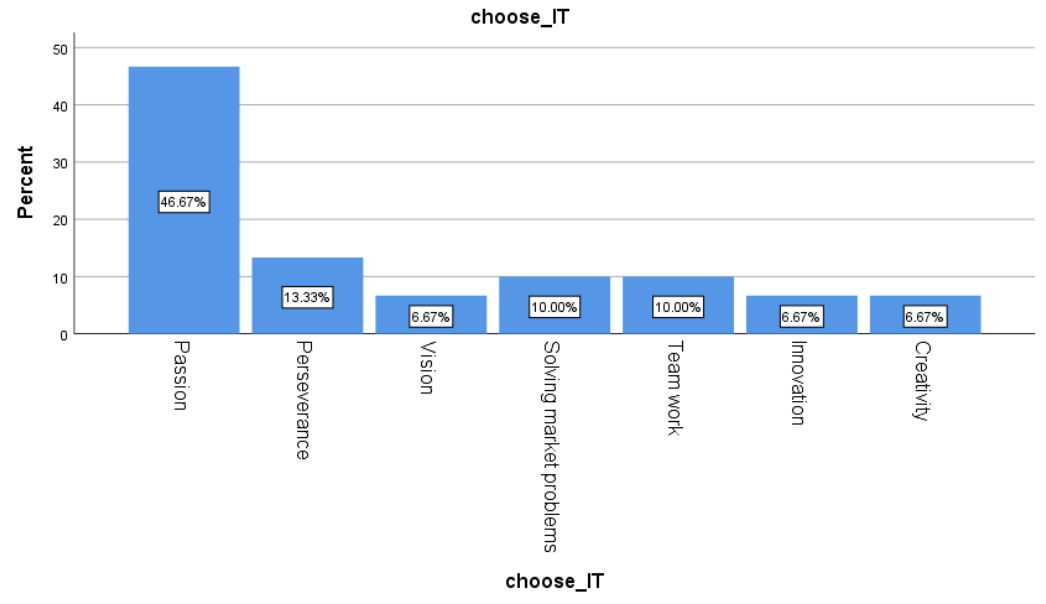

Source: The authors.

Figure 6. Choose IT self-considered future second-age entrepreneurs

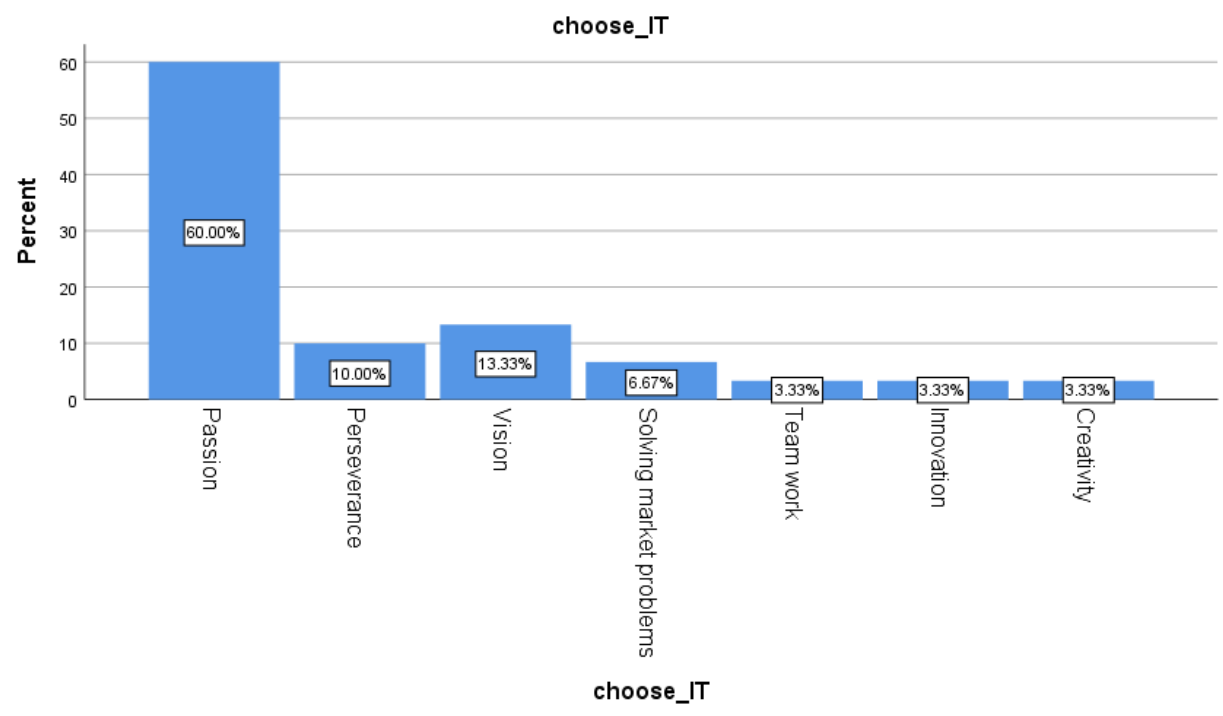

Source: The authors.

In both cases, passion leads future entrepreneurs to start a start-up, followed by perseverance. $46.7 \%$ for self-considered future young entrepreneurs, followed by the idea of perseverance $13.3 \%$. And $60 \%$ for self-considered future second-age entrepreneurs. Before entrepreneurs open a start-up, they need to be passionate about a particular field. Because passion is more important than a plan because it instils energy. In addition, passion is the fuel for an entrepreneur (Maxwell, 2012) to get where he wishes, when others will say not to continue because he will fail. So what distinguishes enthusiastic entrepreneurs and those lacking in talent is enthusiasm, which is manifested in passion (Idem).

It was also found that IT is usually meant for men, but women have started lately to have a say. This domain is not just for men, as with the other domains that were formerly intended exclusively for them (Hampton et al., 2009; Hampton et al., 2009). 
Question no. 3 How could the EU support you in this area of activity?

Figure 7. EU support IT self-considered future young entrepreneurs

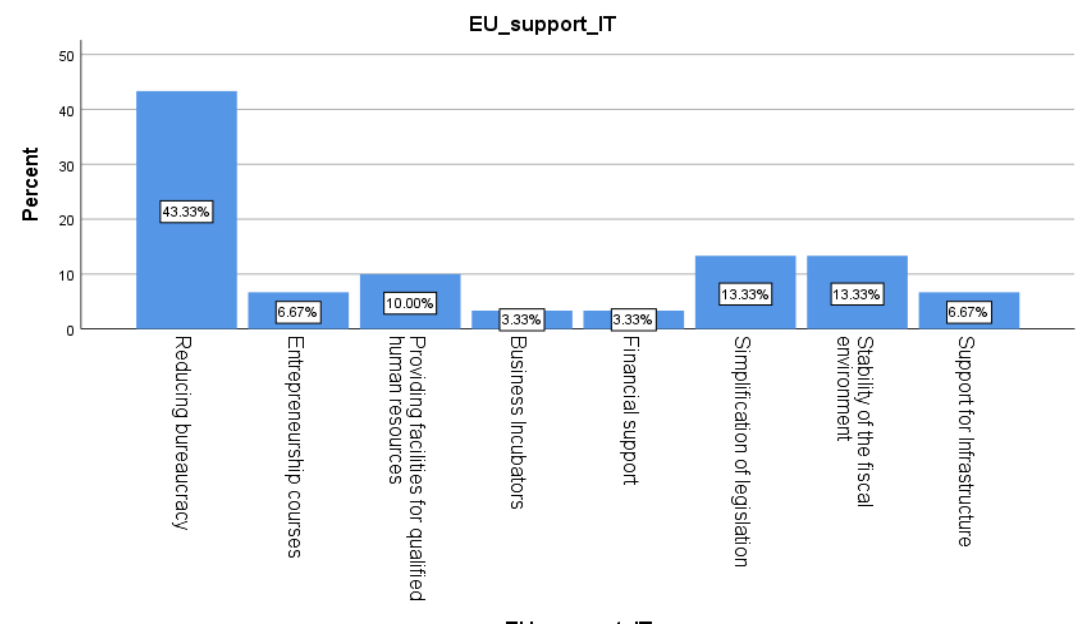

Source: The authors.

Figure 8. EU support IT self-considered future second-age entrepreneurs

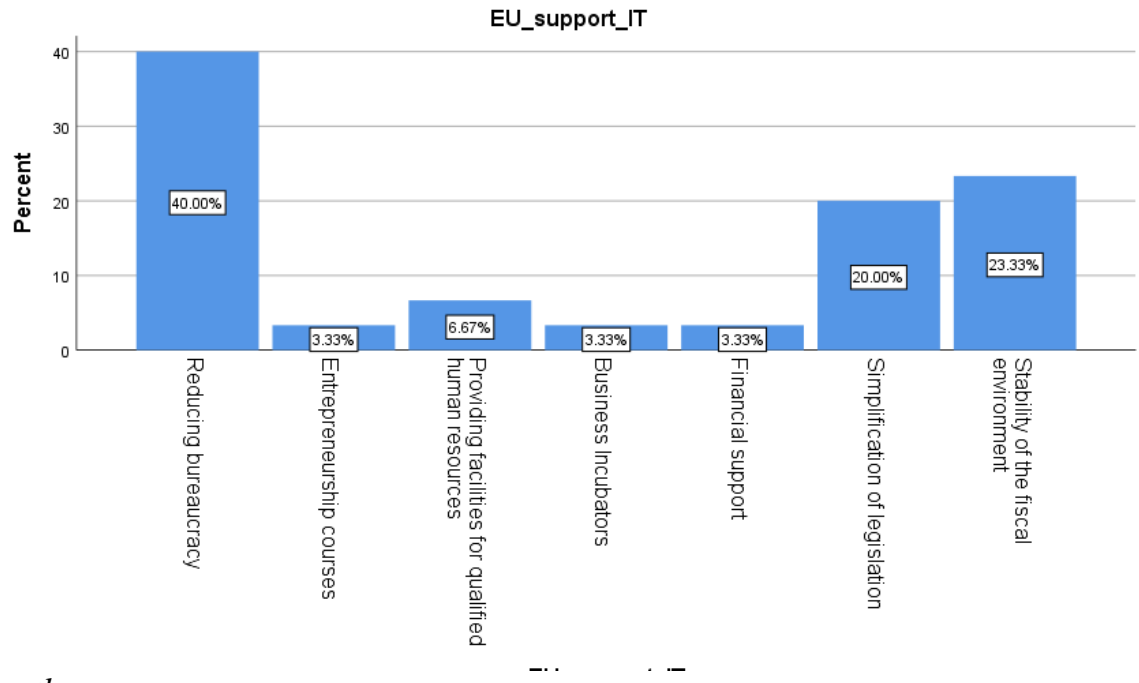

Source: The authors.

44\% self-considered future young entrepreneurs have chosen reducing bureaucracy, while $40 \%$ self-considered future second-age entrepreneurs. As we can see the data is close in size. Followed by simplification of legislation and stability of the fiscal environment for self-considered future young entrepreneurs $14 \%$. In the self-considered future second-age entrepreneurs case, $24 \%$ stability of the fiscal environment and $20 \%$ simplification of legislation. Also, the entrepreneur has to focus on the training courses of his employees, and if they face certain financial problems, entrepreneurs can turn their attention to the sources of funding received from the European Union. Regarding Romania as an EU Member State for entrepreneurial activity, it is recommended to intensify the dialogue and strengthen it through cooperation between the political and public actors and the research institutions of the two entities (Jitaru and Popescul, 2017). 
B. Opportunities to become an entrepreneur: Innovations (the number of new products or services placed on the market).

Question no. 4. How many innovations will you bring to the Romanian market?

Figure 9. How many innovations self-considered future young entrepreneurs

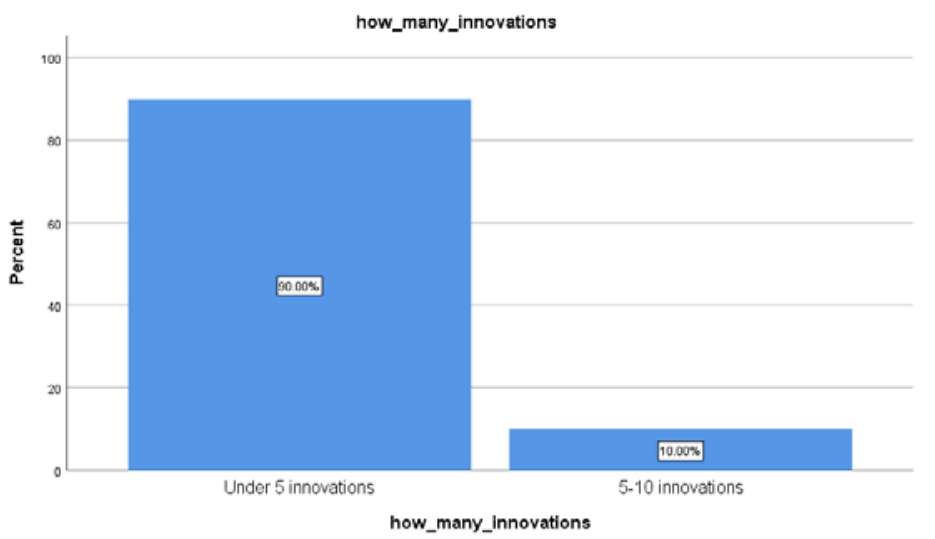

Source: The authors.

Figure 10. How many innovations self-considered future second-age entrepreneurs

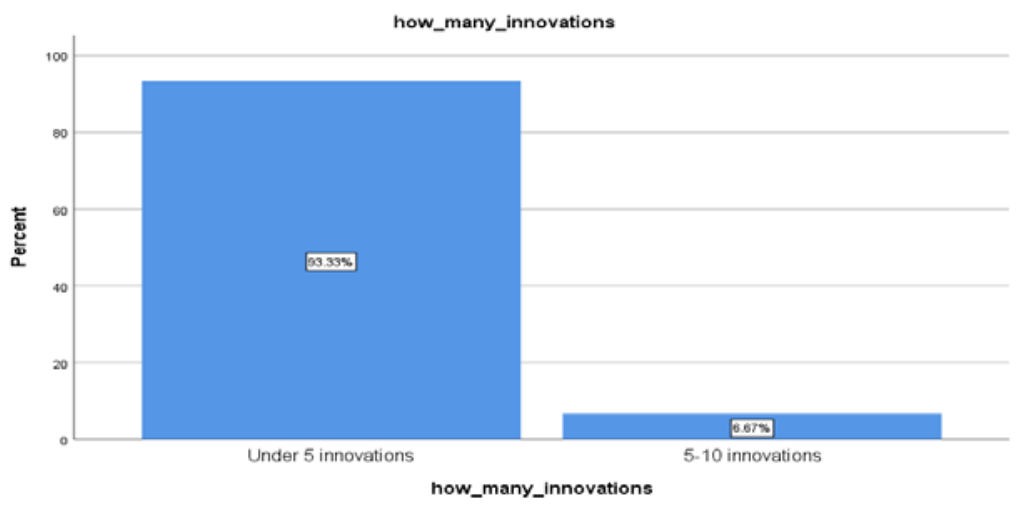

Source: The authors.

$90 \%$ of self-considered future young entrepreneurs will bring under 5 innovation to the Romanian market, while $93 \%$ of self-considered future second-age entrepreneurs will bring under 5 innovation to the Romanian market. In terms of funding sources, entrepreneurs also have other mechanisms to act to start a business, even when the institutional environment is not well developed (Ali et al., 2019). A solution that can be used by IT entrepreneurs, as well as in other areas, is to search for sources of funding on crowdfunding platforms that aim at appealing to a community as a potential financier in order to develop a product, to develop more innovations in their field of activity. Question no. 5. What innovations will you introduce to the Romanian market? 
Figure 11. Innovations introduce market self-considered future young entrepreneurs

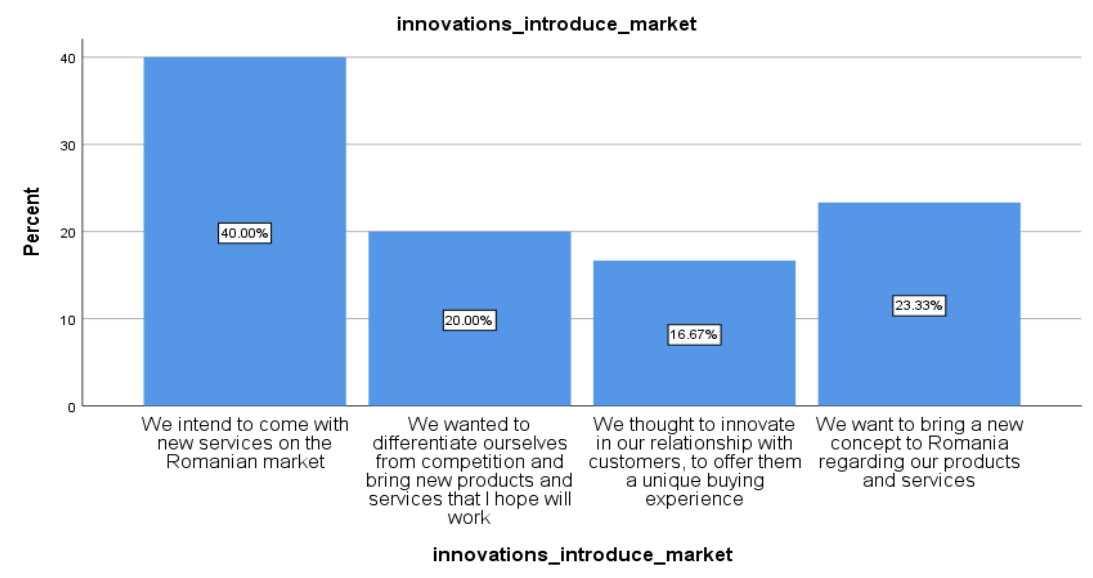

Source: The authors.

Figure 12. Innovations introduce market self-considered future second-age entrepreneurs

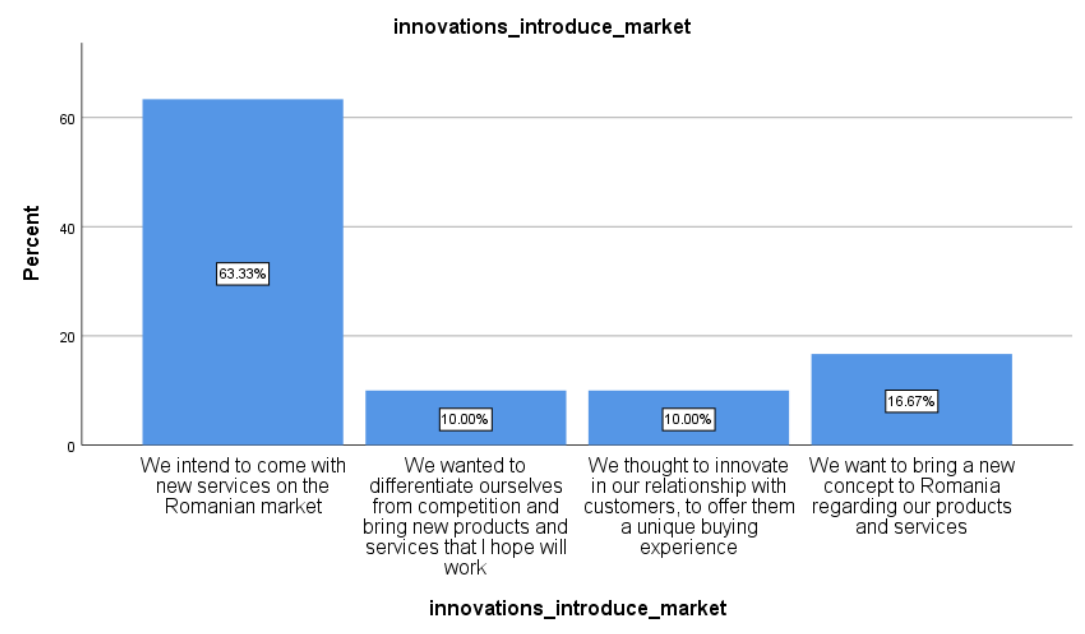

Source: The authors.

$40 \%$ of self-considered future young entrepreneurs intend to come with new services on the Romanian market, followed by differentiate ourselves from competition and bring new products and services that I hope will work, 20\%. While 64\% of selfconsidered future second-age entrepreneurs intend to come with new services on the Romanian market, followed by differentiate ourselves from competition and bring new products and services that I hope will work, 10\%. For start-up businesses to grow, entrepreneurs need to build a strong team to learn to grow and develop teams to achieve remarkable performance (Maxwell, 2005). This can be done by the entrepreneur by recruiting the most valuable people who have the greatest potential.

Question no. 6. What makes you come up with new innovations? 
Figure 13. Come up new innovation self-considered future young entrepreneurs

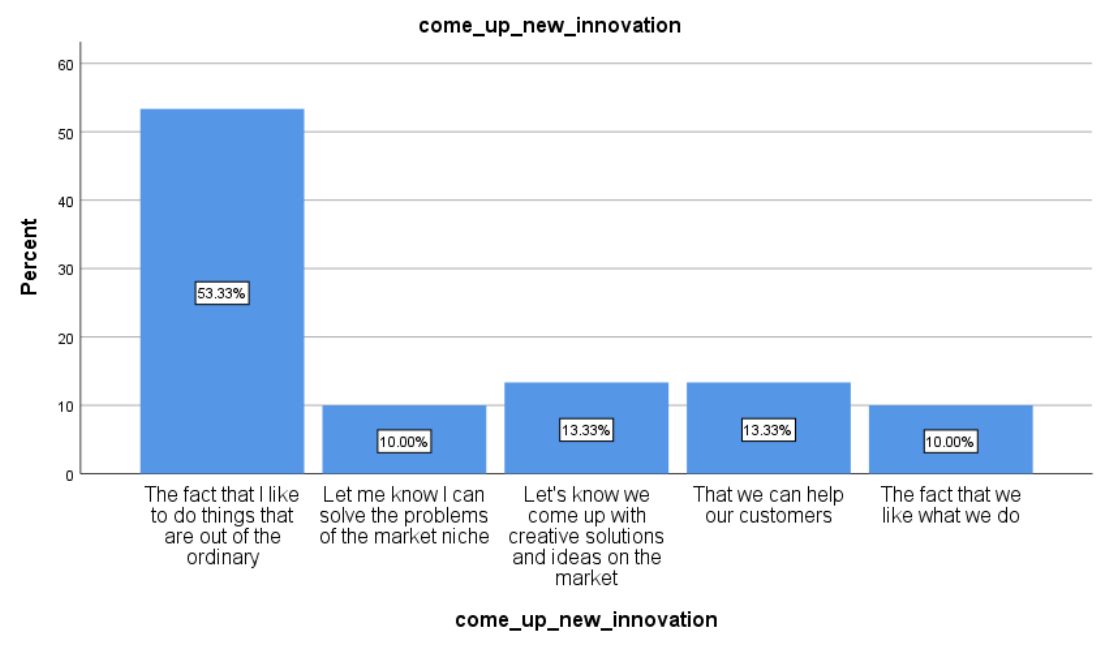

Source: The authors.

Figure 14. Come up new innovation self-considered future second-age entrepreneurs

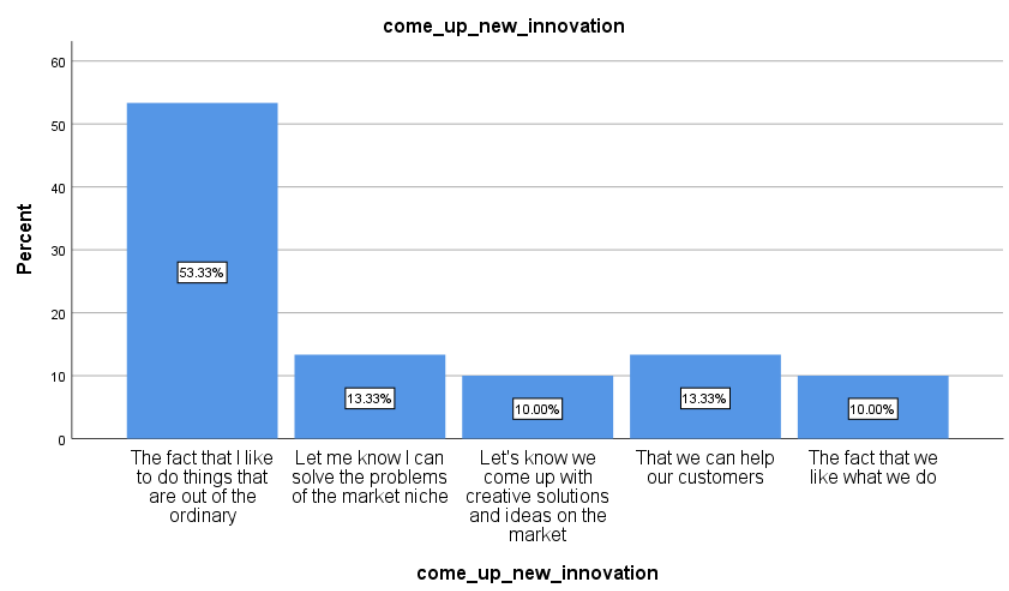

Source: The authors.

$54 \%$ of self-considered future young entrepreneurs answered the fact that I like to do things that are out of the ordinary and $10 \%$ let me know I can solve the problems of the market niche. The same case is for $54 \%$ of self-considered future second-age entrepreneurs I like to do things that are out of the ordinary, $14 \%$ let me know I can solve the problems of the market niche and 10\% let's know we come up with creative solutions and ideas on the market. Romania needs an innovation driven economy. However, this type of economy is generally specific to countries that have a fairly high standard of living and which is usually associated with high wages that are also generated by innovative businesses. Innovative businesses are primarily competitive precisely because they offer new or even unique products (Barta et al., 2013).

C. Satisfaction with the quality of personal and professional life: balancing personal life and professional life (the number of hours spent in professional and professional life). 
Question no. 7. What does your personal life and professional life mean for you?

Figure 15. Personal life and professional life self-considered future young entrepreneurs

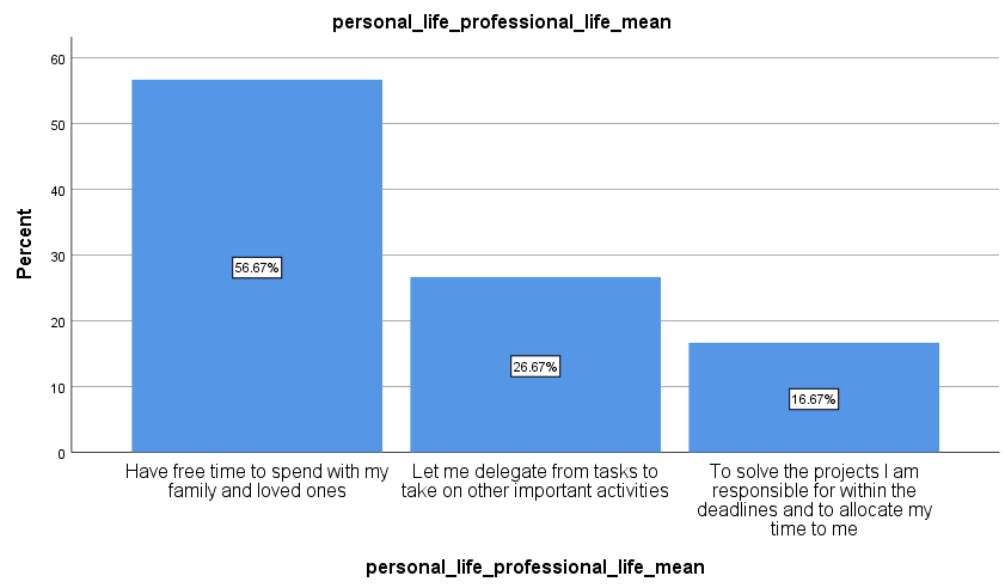

Source: The authors.

Figure 16. Personal life and professional life self-considered future second-age entrepreneurs

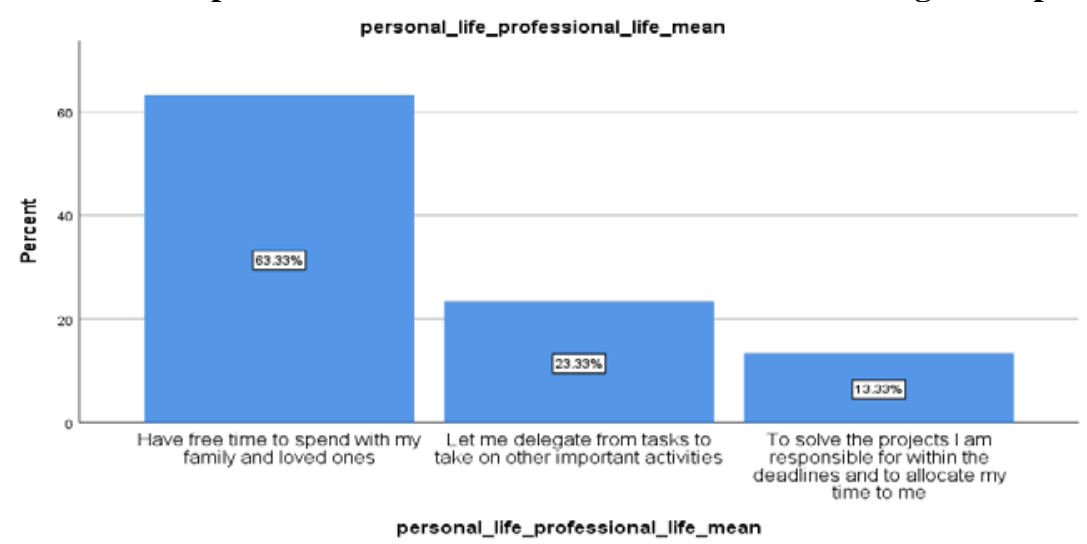

Source: The authors.

$57 \%$ of self-considered future young entrepreneurs answered have free time to spend with my family and loved ones, followed by $27 \%$ of self-considered future young entrepreneurs answered let me delegate from tasks to take on other important activities While $64 \%$ of self-considered future second-age entrepreneurs answered have free time to spend with my family and loved ones, followed by $24 \%$ of self-considered future secondage entrepreneurs answered let me delegate from tasks to take on other important activities. Entrepreneurs are no longer in a balance between personal and professional life (Papulová and Mokroš, 2007), and here are a series of phenomena such as anxiety, frustrations, burnout, various problems in personal and professional life (Cacciotti and Hayton, 2015; Gondim and Mutti, 2011).

Question no. 8. How many average hours do you dedicate to weekly business activities? 
Figure 17. Hours dedicate to weekly business activities self-considered future young entrepreneurs

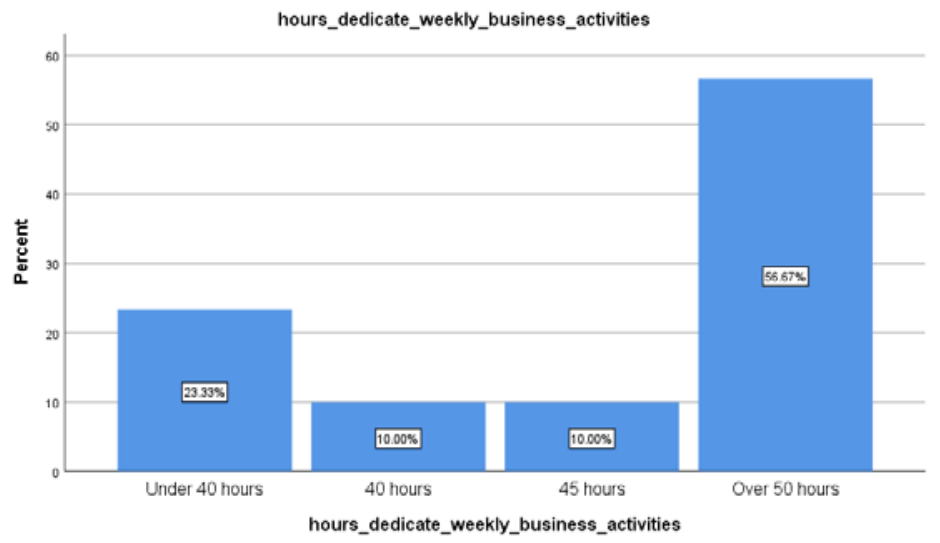

Source: The authors.

Figure 18. Hours dedicate to weekly business activities self-considered future second-age entrepreneurs

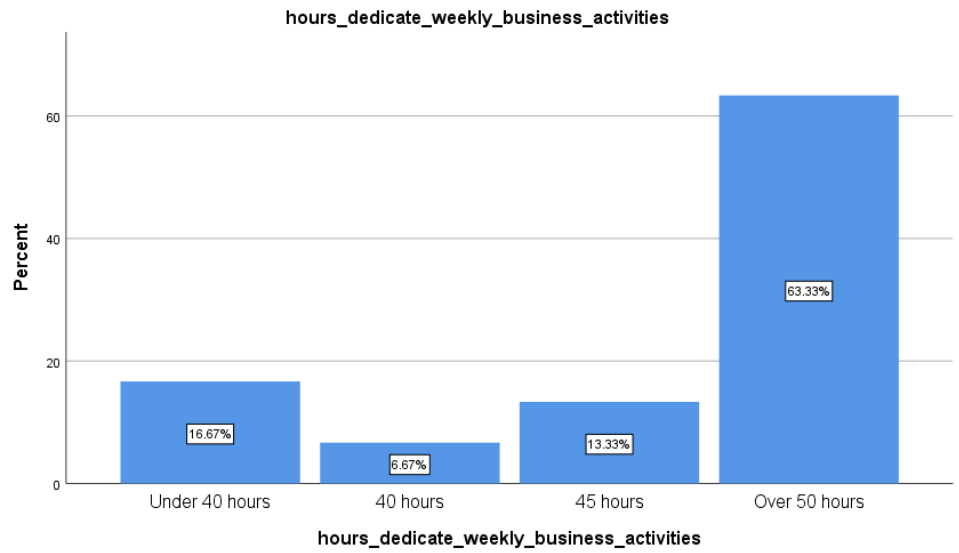

Source: The authors.

$57 \%$ of self-considered future young entrepreneurs answered over 50 hours dedicate to weekly business activities, followed by $24 \%$ of self-considered future young entrepreneurs answered under 40 hours dedicate to weekly business activities.

$64 \%$ of self-considered future second-age entrepreneurs answered over 50 hours dedicate to weekly business activities, followed by $17 \%$ of self-considered future secondage entrepreneurs answered under 40 hours dedicate to weekly business activities. Also, the Romanian entrepreneurs have the gift of dedication as well as of an overwhelming energy when it comes to their business, so they work 7 days in 7, 24 hours for a long time and even years (Ghenea, 2011, p.313-315).

Question no. 9. How many hours on average do you dedicate to free time per week? 
Figure 19. Hours dedicate to free time per week self-considered future young entrepreneurs

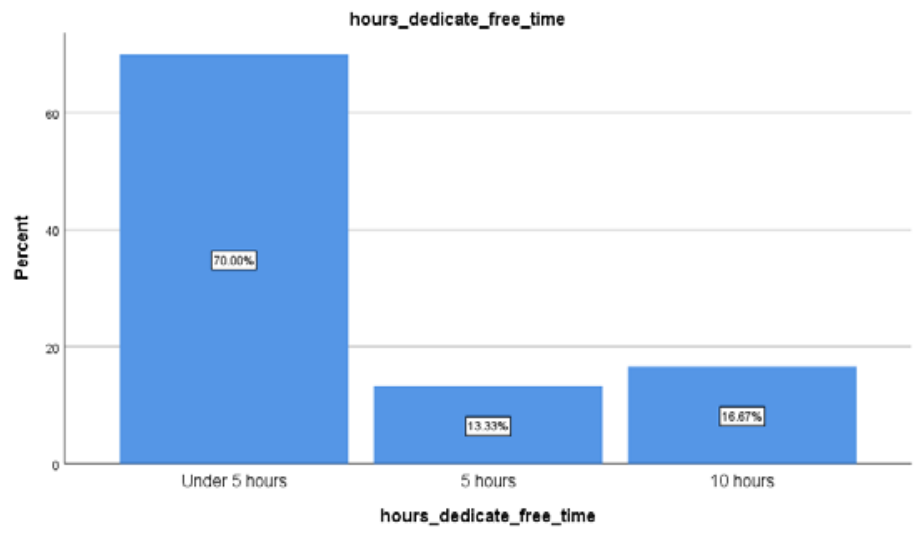

Source: The authors.

Figure 20. Hours dedicate to free time per week self-considered future young entrepreneurs

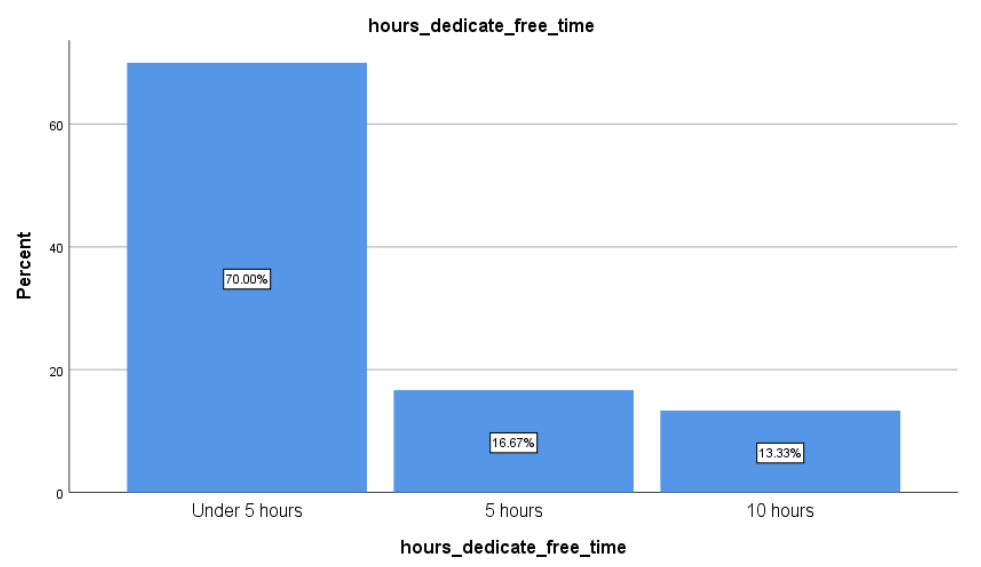

Source: The authors.

In both case, $70 \%$ of self-considered future young entrepreneurs and $70 \%$ of selfconsidered future second-age entrepreneurs answered under 5 hours to free time per week self-considered future young entrepreneurs. We found that passion is the one that motivates entrepreneurs to take the first step towards realization, strengthens their will and gives them energy (Maxwell, 2008).

For the third part, we asked the entrepreneurs to complete this table:

For the question (3) What do you think are the opportunities, responsibilities and challenges that Romania can benefit from as an EU member state and economic growth and development ?, the entrepreneurs responded:

Table 6. The relationship between the opportunities, responsibilities and challenges that Romania can benefit as an EU member state and growth and economic development - self-considered future young entrepreneurs and self-considered future second-age entrepreneurs

\begin{tabular}{|l|l|l|}
\hline Opportunities & Responsibilities & Challenges \\
\hline $\begin{array}{l}\text { Learning and adapting best practices from } \\
\text { the experience of other companies across } \\
\text { the EU. }\end{array}$ & $\begin{array}{l}\text { Increase in the number of } \\
\text { entrepreneurial programs at national } \\
\text { level by attracting EU funds. }\end{array}$ & $\begin{array}{l}\text { The level of } \\
\text { taxation. }\end{array}$ \\
\hline Financial education by experts in the field. & Reducing the bureaucratic system. & Access to finance. \\
\hline
\end{tabular}




\begin{tabular}{|l|l|l|}
\hline $\begin{array}{l}\text { Developing human capital by offering } \\
\text { training and specialization courses. }\end{array}$ & $\begin{array}{l}\text { Providing tax incentives for the } \\
\text { entrepreneur to no longer feel } \\
\text { overwhelmed. }\end{array}$ & Taxation. \\
\hline $\begin{array}{l}\text { Providing facilities for qualified human } \\
\text { resources. }\end{array}$ & Stability of the fiscal environment. & Corruption. \\
\hline Creating business incubators. & Focusing on R \& D and innovation. & Globalization. \\
\hline $\begin{array}{l}\text { Financial resources provided through EU } \\
\text { support. }\end{array}$ & $\begin{array}{l}\text { Fluidizing access to finance and } \\
\text { business information. }\end{array}$ & Competition. \\
\hline $\begin{array}{l}\text { Providing coaching and mentoring to start- } \\
\text { up entrepreneurs from senior } \\
\text { entrepreneurs. }\end{array}$ & $\begin{array}{l}\text { Investing in technology to have quality } \\
\text { products and services. }\end{array}$ & $\begin{array}{l}\text { The financial } \\
\text { crisis. }\end{array}$ \\
\hline $\begin{array}{l}\text { New sources of investment. } \\
\text { Developing business infrastructure. }\end{array}$ & Infrastructure development. & $\begin{array}{l}\text { Migration } \\
\text { labor abroad. }\end{array}$ \\
\hline Developing e-commerce. & Simplifying administrative procedures. & $\begin{array}{l}\text { Economic } \\
\text { decline. }\end{array}$ \\
\hline Stimulating competition. crisis. & Rising prices. \\
\hline Modernizing business models. & & The fiscal crisis. \\
\hline Foreign direct investment. & & \\
\hline Developing business infrastructure. & & \\
\hline $\begin{array}{l}\text { Providing consultancy from various } \\
\text { specialists: accounting, taxation, } \\
\text { management, human resources, etc. }\end{array}$ & & \\
\hline
\end{tabular}

Source: The authors.

Thus, one of Romania's responsibilities towards young entrepreneurs and the second-age entrepreneurs at the start-up level is related to the increase in the number of entrepreneurial programs at national level by attracting EU funds, reducing the bureaucratic system, but also by providing facilities tax policy that makes the entrepreneur no longer burdened. One of the challenges facing Romania is also to make technological changes that might be possible by making a joint effort between research and academia and organizations to enhance their research, innovation and to increase its contribution to the part of the development of society (Rosca and Păunescu, 2010). In the case of entrepreneurs, problems are those that create opportunities (Trump and Kiyosaki, 2008). So the European Union can support start-ups through entrepreneurship courses, providing facilities for qualified human resources, business incubators and financial resources. Also essential is the support of local and central government for entrepreneurs by reducing bureaucracy and simplifying legislation, the stability of the tax environment.

After analyzing the data, we found that the entrepreneurs mentioned the idea of corruption. The idea is that entrepreneurship can be positively or negatively affected by corruption. The positive effect occurs when the bribe allows new companies to buy their seats on the waiting list by obtaining government contracts. On the other hand, corruption acts as an entry barrier for new entrants because it imposes additional costs for doing business (Goel and Saunoris, 2018). The challenge in this regard is to adopt anti-bribery legislation in Romania. Especially in Romania, corruption is perceived as a very serious problem (Bąkowski and Voronova, 2017).

We propose that Romania adopt the model in Estonia that managed to carry out an administrative reform that aimed at reducing bureaucracy and corruption. Especially because corruption creates a series of legislative obstacles. If we are referring to Estonia 
and Romania, both countries have come out almost simultaneously from communism, but both countries are at the extremes of digitization. An example adopted by Estonia, in this regard, may be that taxes are paid online, which automatically lowers tax evasion and increases the collection rate, and the list can continue.

An aspect that can scare entrepreneurs to start a start-up can be related to the migration of Romanian specialists. However, it should not be seen as a bad thing because mobility indicates that people have the skills and education they need to found jobs in developed economies, which in the future will lead to Romania's development.

In this case, entrepreneurs who can provide coaching and mentoring to start-up entrepreneurs through hubs and business incubators also play a significant role.

We note that the characteristics and qualities required for a successful entrepreneur who wants to open a start-up include both charisma, vision, persuasion, intelligence and creativity, but also responsibility, perseverance and determination in what he proposes to realize. At the same time, the entrepreneur needs to know your business in the smallest detail. In addition, the entrepreneur has decision-making skills, problem solving, positive thinking, must have passion for business, personal ethics, trust and correct attitude towards his own people, entrepreneurial flair (Popescul, 2017).

We also note that if in some cases there are entrepreneurs who do not necessarily seek to open up a start-up business, they still decide to become entrepreneurs as a way to overcome the lack of employment opportunities, indicating that they try to avoid the risks. (Mota, 2019). With the statement that in this case, such entrepreneurs will not go too far with their own businesses. They will fail in their first three years of activity because they lack the knowledge, skills and competencies needed to grow and develop a business. In addition, a person who wants to become an entrepreneur must first be passionate about the field when he opens the business, sees opportunities when others see problems and is willing to take risks,

Also, this research study shows that at present we can no longer speak of IT as exculpable to men, given that women today account for half of the world's population. Which implies equal access to health, economic participation, education, and political decision-making (WEF), Global Gender Gap Report, 2016.

As the European Commission (2014, p.3) also claims, ' the EU is facing extremely high international competition in the field of research as well as in technological production. In this respect, efforts are moving towards the transposition of innovative ideas into new successful products and technologies."

Reaching objectives and validating hypotheses:

O1: Analysis of entrepreneurial skills on entrepreneurial behaviour - is attained.

H1: Passion positively influences the decision to open a start-up - it is accepted.

O2: Analysis of Opportunities to Become an Entrepreneur on the Behaviour of Entrepreneurs - is Attained.

H2: Innovation positively influences the decision to open a start-up - it is accepted.

O3: Analysis of the satisfaction with the quality of personal and professional life on the behaviour of entrepreneurs - is achieved.

H3: The balance between personal life and professional life positively influences the decision to open a start-up - it is accepted.

Therefore, following the analysis of the specialized literature and the interpretation of the obtained data, we have developed a model that takes into account the behaviour of the 
future entrepreneurs who want to open a business, so the intention of the entrepreneurs is manifested in this case.

Therefore, we obtained the following model for the development of a start-up through the European Union, figure 21 as follows:

Figure 21. Model for the development of a start-up through the European Union

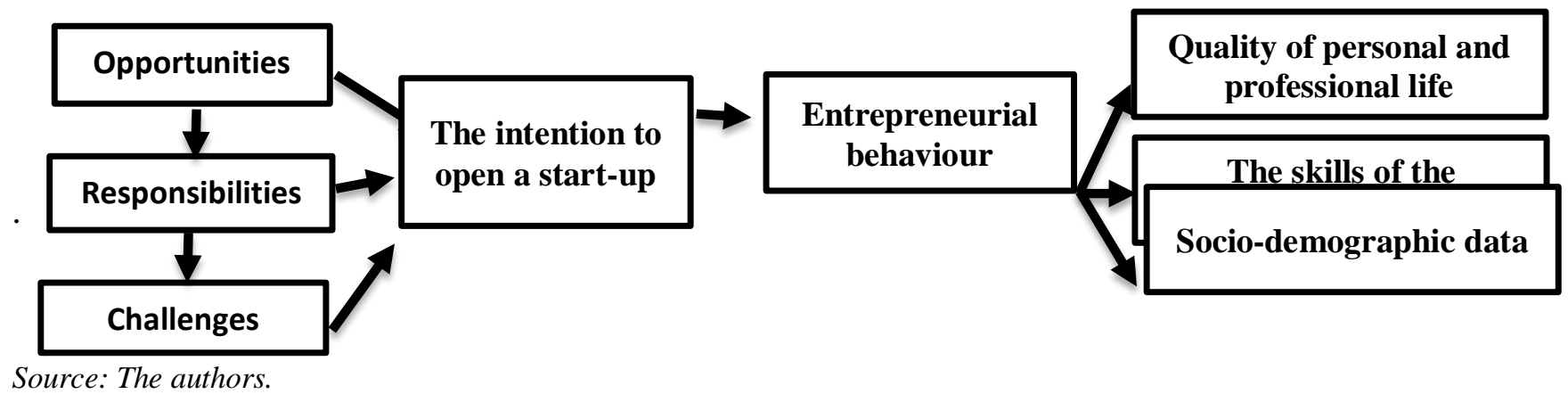

The success of entrepreneurs is closely related to environmental factors and the willingness of individuals to change (Ratten et al., 2019). At the same time, knowledge about market trends, planning skills and the ability to think strategically (Idem) is needed. At the same time, if entrepreneurs plan to start a start-up business, but in the past they have failed, they should be encouraged not to give back. In life, people sometimes make mistakes, but this does not prevent them from going further and learning new lessons. Thus a failure is a temporary event and not a disease for a long time (Maxwell, 2005).

As in the study conducted by Mota et al. (2019), entrepreneurial motivations are strongly correlated with the entrepreneurial socio-demographic data, such as age, education, and family income. With the statement that in our study we did not take into account the income of the family variable, but rather we went to the most developed cities in Romania, that is why we chose the city from which the entrepreneurs come from.

\section{Conclusions}

Regarding the part of the responsibilities and challenges that Romania faces, they are also numerous in terms of entrepreneurial activity, but they must be minimized and transformed into new business opportunities. And in this case, Romania can adopt both the model of Estonia and other countries that have focused primarily on research, development and innovation, see for example the case of Switzerland. Romania could benefit from the opportunities to learn and adapt best practices from the experience of other companies within the EU. However, entrepreneurs need to be encouraged to do so by exchanging good practice. Creating business premises, whether they be hubs or business incubators, they allow entrepreneurs to come up with innovative ideas. They need space to test and chat with other entrepreneurs in the same field or in different areas to get valuable performance. We recommend that in the future continue this study and analyze businesses with over 3 years of experience in the field to perform a comparative analysis. In this case, we thought it would be useful to analyze the following variables: number of employees, team productivity, team effectiveness and sales volume. 
Our study shows that entrepreneurs are looking for new ideas in order to innovate. This is because technology has evolved, and competition is a fierce one in this area of IT. In the field of IT things are happening very fast, so what works today, tomorrow may not be the same, which is a plus of value and an evolution of the way things are happening today. It is just that all this at one point starts to put increasing pressure on IT and IT entrepreneurs in general, which can lead to the burnout phenomenon. Especially that entrepreneurs work 7 days in 7 and 24 in 24 hours, which affects their personal and professional lives.

Data can not be generalized because the sample is not a representative one. We propose that this questionnaire be applied to a considerably larger number of future entrepreneurs, precisely in the idea of coming up with solutions, recommendations and ideas for them. In order to support the future entrepreneurs at the beginning of the road. This study has limitations on work methodology, specificity so future studies may use other research methods or replicate the methodology proposed in this study with another group of decision-makers such as entrepreneurs in the first 3 years of activity or even experienced entrepreneurs. In this way, a broad comparative analysis can be made to attract other ideas, solutions, recommendations, and feedback.

\section{References}

1. Akcigit, U., Alp, H., \& Peters, M. (2021). Lack of selection and limits to delegation: firm dynamics in developing countries. American Economic Review, 111(1), 231-75. DOI: 10.1257/aer.20180555

2. Ali, A., Kelley, D. J., Levie, J. (2019), Market-driven entrepreneurship and institutions, Journal of Business Research (retrieved from https://doi.org/10.1016/j.jbusres.2019.03.010).

3. Barta et al. (2013), Inovarea și antreprenoriatul piloni ai competitivității, Fundația Post-Privatizare.

4. Bąkowski, P. and Voronova, S. (2017), Corruption in the European Union. Prevalence of corruption, and anti-corruption efforts in selected EU Member States, EPRS, European Parliamentary Research Service, Study.

5. Cacciotti, G., Hayton, J. C. (2015), Fear and Entrepreneurship: A Review and Research Agenda, International Journal of Management Reviews, 17, 165-190, https://doi.org/10.1111/ijmr.12052

6. Collinson, E., Shaw, E. (2001), Entrepreneurial marketing-a historical perspective on development and practice, Management Decision, 39(9), 761-766, https://doi.org/10.1108/EUM0000000006221

7. Comisia Europeană (2014), Să înțelegem politicile Uniunii Europene: Cercetare și inovare. Depășirea limitelor și îmbunătățirea calității vieții, Luxemburg: Oficiul pentru Publicații al Uniunii Europene.

8. Dumitraşciuc, L. F. (2019), How entrepreneurs words impact their success. life coach perspective, Journal of Public Administration, Finance and Law, 15, 101-106.

9. Dumitrașciuc, L. F., Jitaru, L. (2019), The Influence of the Life Coaching Process on Entrepreneurial Talents in Romania, “Ovidius” University Annals, Economic Sciences Series, Volume 19(1), pp. 427-431.

10. Galindo, M.-Á., Méndez, M. T. (2014), Entrepreneurship, economic growth, and innovation: Are feedback effects at work?, Journal of Business Research, 67, 825-829, https://doi.org/10.1016/j.jbusres.2013.11.052

11. Ghenea, M. (2011), Antreprenoriat. Drumul de la idei către oportunități și succes în afaceri, Editura Universul Juridic, București, pp. 313-315.

12. Goel. R. K., Saunoris, J. W. (2019), International corruption and its impacts across entrepreneurship types, Manage Decis Econ., 1-13, https://doi.org/10.1002/mde.3017

13. Gondim, S. M., Mutti, C. (2011), Affections in learning situations: a study of an entrepreneurship skills development course, Journal of Workplace Learning, 23(3), 195-208, https://doi.org/10.1108/13665621111117224 
14. Hampton, A., Cooper, S., Mcgowan, P. (2009), Female Entrepreneurial Networks and Networking Activity in Technology-based Ventures: An Exploratory Study, International Small Business Journal: Researching Entrepreneurship, 27(2), https://doi.org/10.1177\%2F0266242608100490

15. Hampton, A., Mcgowan, P., Cooper, S. (2011), Developing quality in female high-technology entrepreneurs' networks, International Journal of Entrepreneurial Behavior \& Research, 17 (6), https://doi.org/10.1108/13552551111174684

16. Fuentelsaz, L., González, C., Maícas, J.P., Montero, J. (2015), How different formal institutions affect opportunity and necessity entrepreneurship, Bus. Res. Q, 18, 246-258, https://doi.org/10.1016\%2Fj.brq.2015.02.001

17. Jitaru, L., Popescul, L. F. (2017), The EU-China cooperation to promote sustainable development, Annals of the ,Constantin Brâncuşi” University of Târgu Jiu, Economy Series, Issue 4.

18. Kalirajan, K. P., Shand, R. T. (1994), On Modelling Agricultural Entrepreneurship, Indian Journal of Agricultural Economics, 49(1), 79-87.

19. Kautonen, T. (2008), Understanding the older entrepreneur: comparing third age and prime age entrepreneurs in Finland, Int. J. Bus. Sci. Appl. Manage, 3, 3-13.

20. Kautonen, T., Tornikoski, E.T., Kibler, E. (2011), Entrepreneurial intentions in the third age: the impact of perceived age norms, Small Bus. Econ. 37, 219-234, https://doi.org/10.1007/s11187-009-9238-y

21. Kelley, D. (2009), Growth aspirations as a function of entrepreneurial motivations and perceptions, Babson Faculty Research Working Papers, 49.

22. Onofrei, M., Cărăușu, D. N., \& Lupu, D. (2019). The role of the macroeconomic environment in shaping capital market co-movement in CEE countries. Economic research-Ekonomska istraživanja, 32(1), 3813-3834, https://doi.org/10.1080/1331677X.2019.1675525

23. Maxwell, J. (2012), Cele 5 niveluri ale leadershipului, Editura Amaltea, București, pp. 225.

24. Maxwell, J. (2008), Talentul nu este suficient. Descoperă opțiunile care te vor purta mai departe decât îți permite talentul, Editura Amaltea, București, pp. 128.

25. Maxwell, J. (2005), Totul despre lideri, atitudine, echipă, relații, Editura Amaltea, București, pp.

128.

26. Mota, A., Braga, V., Ratten, V. (2019), Entrepreneurship Motivation: Opportunity and Necessity, Sustainable Entrepreneurship, 139-165, https://doi.org/10.1007/978-3-030-12342-0_8

27. Papulová, Z., Mokroš, M. (2007), Importance of managerial skills and knowledge in management for small entrepreneurs, E-Leader Prague

28. Popescul, L. (2017), Entrepreneurship. The Road to Ideas to Opportunities and Business Success, International Journal of Entrepreneurial Behavior \& Research, Volume 23, Issue: 5, 839-841, https://doi.org/10.1108/IJEBR-08-2017-405

29. Ratten, V., Jones, P., Braga, V., Marques, C. S. (2019), Sustainable Entrepreneurship: The Role of Collaboration in the Global Economy, Sustainable Entrepreneurship, https://doi.org/10.1007/978-3-03012342-0_1).

30. Roşca, I. Gh., Păunescu, C. (2010), Shaping the future of higher education in Romania: challenges and driving factors, Management \& Marketing, 5(1), 57-70.

31. Trump, D. and Kiyosaki, R. T. (2008), De ce vrem să fii bogat: doi oameni, același mesaj, Editura Curtea Veche, București.

32. Uniunea Europeană (2019) (retrieved from https://europa.eu/european-union/topics/researchinnovation_ro).

33. WEF (2016), Global Gender Gap Report (retrieved from http://reports.weforum.org/globalgendergap-report-2016/the-case-for-gender-parity/).

34. Wennekers, S., Van Stel, A., Carree, M., Thurik, R. (2010), The Relationship Between Entrepreneurship and Economic Development: Is It U-Shaped? Now Publishers Inc.

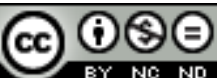
EY NO ND This article is an open access article distributed under the terms and conditions of the Creative Commons Attribution - Non Commercial - No Derivatives 4.0 International License. 